\title{
Immunostimulatory Activity of Aqueous Extract of Polyherbal Formulation on Th1/Th2 Cytokines Secretion and Cell Mediated Immune Response in Rats
}

Hamid $\mathrm{KM}^{1}$, Isah $\mathrm{SY}^{1,2^{*}}$, Kalgo $\mathrm{MU}^{1}$, Isiyaku $\mathrm{A}^{1}$, Usman $\mathrm{AB}^{1}$, Yeldu $\mathrm{MH}^{3}$, Yusuf $\mathrm{A}^{4}$, Abubakar, $\mathrm{NK}^{5}$, Garba $\mathrm{YB}^{6}$, Muhammad $\mathrm{HY}^{7}$

${ }^{1}$ Department of Immunology, School of Medical Laboratory Sciences, Usmanu Danfodiyo University, P.M.B. 2346, Sokoto, Nigeria

${ }^{2}$ Department of Medical Laboratory Science, Faculty of Allied Health Sciences, Bayero University, P.M.B. 3011, Kano, Nigeria

${ }^{3}$ Department of Chemical Pathology, School of Medical Laboratory Sciences, Usmanu Danfodiyo University, P.M.B. 2346, Sokoto, Nigeria

${ }^{4}$ Department of Medical Laboratory Sciences, Faculty of Allied Health Sciences, Kaduna State University, P.M.B. 2339, Kaduna, Nigeria

${ }^{5}$ Department of Health Services, Federal University Birnin Kebbi, P.M.B. 1157, Kebbi, Nigeria

${ }^{6}$ National Tuberculosis and Leprosy Training Centre, P.M.B. 1089, Zaria, Kaduna, Nigeria

${ }^{7}$ Department of Chemical Pathology, Aminu Kano Teaching Hospital, P.M.B. 3452, Kano, Nigeria

DOI: $10.36348 /$ sjmps.2021.v07i01.013

| Received: 28.12.2020 | Accepted: 11.01.2021 | Published: 28.01.2021

*Corresponding author: Isah Sulaiman Yahaya

\section{Abstract}

Some formulations possess the ability to stimulate or suppress immune system thus may be important in controlling various disease condition or lead to undesirable prospect. Studies on immunomodulatory agent can leads to isolation of acceptable and reliable pharmacological agent with wider application. This study evaluate the immunostimulatory activity of Polyherbal Formulation (PHF) on Th1/Th2 cytokines secretion and cell mediated immune response in Wistar Rats. Twenty four (24) Wistar rats were randomly divided into six group and each group contains four rats. Group 1 received normal saline as normal control, Group 2 received Levamisole $\mathrm{Hcl}$ as positive control, Group 3 received Cyclophosphamide as negative control, while Group 4 - 6 received different concentration of aqueous extract of PHF. Blood was collected and processed to obtain a serum. The serum was used for Th1 (IL-2, IFN- $\gamma$ ) and Th2 (IL-4, IL-6,) cytokines analysis using ELISA techniques. Keyhole Limpet Hemocyanin was used as antigen to induce Delayed type hypersensitivity (DTH) response. Footpad thickness was measured using digital vernier calliper. There was significant increase in serum concentration of IL-2, IFN- $\gamma$, IL-4 and IL- 6 across the treatment groups with increase in dose of PHF ( $\mathrm{p}<0.001)$. There was significant increase in DTH response across the treatment groups in dose-dependent manner $(\mathrm{p}<$ 0.001). The PHF has immunostimulatory activity on Th1/Th2 cells thus induce the secretion of the cytokines. It increase DTH response thus can be useful in immune response involving $\mathrm{T}$ lymphocytes. The formulation could be useful in managing immunosuppressed conditions due to its immunomodulatory potential.

Keywords: Cytokines, Hypersensitivity, Immunomodulation, Plant Extracts, Rats, T helper Cells.

Copyright (C) 2021 The Author(s): This is an open-access article distributed under the terms of the Creative Commons Attribution 4.0 International License (CC BY-NC 4.0) which permits unrestricted use, distribution, and reproduction in any medium for non-commercial use provided the original author and source are credited.

\section{INTRODUCTION}

Traditional medicine is the area receiving attention as it serves as source of natural product used for development of pharmacological agents that can yield desired results [1]. Use of plant extracts for treatment of infections and other health condition is prominent in African traditional medicine [2]. Different part of plant materials are processed as herbal formulation, these include root, bark or leaves [3, 4]. These plant materials could be combined together to form a polyherbal formulation for a purpose of diverse pharmacological effect to obtained desired results with minimum side effect $[5,6]$. Some formulations possess the ability to stimulate or suppress immune system thus may be important in controlling various disease condition or leading to undesirable prospect $[7,8]$. Immune system consists of innate, cell mediated and humoral components. A substance that can modulate immune system is referred as immunomodulator [9]. Modulators exert their effect by regulation of mediators or messengers such as cytokines, neurotransmitters etc or facilitate phagocytic function or adhesion of molecules $[10,11]$.

Cytokines are glycoproteins or soluble extracellular proteins required for proliferation and differentiation of immune cells and also guide the type of immune responses [5, 12]. Multidimensional nature of cytokines in terms of sources, targets and functions

Citation: Hamid KM et al (2021). Immunostimulatory Activity of Aqueous Extract of Polyherbal Formulation on Th1/Th2 Cytokines 64 Secretion and Cell Mediated Immune Response in Rats. Saudi J Med Pharm Sci, 7(1): 64-70. 
Hamid KM et al., Saudi J Med Pharm Sci, Jan, 2021; 7(1): 64-70

make them to serve as very important immunomodulatory proteins utilized in treatment of wide range of disease [13]. They exhibit autocrine, paracrine or endocrine function thus can be able to exert either synergistic or antagonistic effect [14]. Furthermore cytokines levels may serve as diagnostic value for assessment of inflammatory process in several disease conditions [15] and indeed immunomodulatory activities of foods or drugs [16]. Cytokines are among the primary target of immunomodulators source from plant materials thus alter immune response [17] by upregulation or down regulation of cytokines or its receptors as such serve as favourable target for therapeutic approaches [13]. The balance between Th1 and Th2 immune responses is dictated by cytokines, because they can shift cell mediated response (Th1) to humoral response (Th2) and vice versa [10]. For instance IL-2, IL-3, IL-12, IFN- $\gamma$ and TNF induce the response away from the humoral immune response $[8$, 18] whereas IL-4, IL-5, IL-6, IL-10 and IL-13 can induce the response towards humoral immune response (Th2) [19]. Some pharmacological agents can alter the balance between Th1 and Th2 which could be advantage to the host. Because the nature of the disease agent determine which type of response is important, for instance intracellular parasites and viruses need Th1 response whereas extracellular organisms need Th2 response [10].

Studies on immunomodulatory agent can lead to isolation of acceptable and reliable pharmacological agent with wider application, [20] especially due to infection such as HIV or malnutrition, stress and some immunologically related conditions such as hypersensitivity, inflammation etc [21, 22], as such this area is attracting research interest worldwide [20]. Besides there is fear of adverse reactions by immunomodulatory agent not from plants origin [23, 24]. Some disease conditions tend to impair immune response [23]. Therefore a modulator that will improve and maintain immune status is necessary [25].

In developing world many people decided to choose medicine from natural source in form of herbal as alternative to improve their health condition $[9,26]$. Combination of plant materials as herbal formulation yielded better and effective results than the individual plant component because it can trigger several signalling pathways [10].

The Polyherbal formulation called "Garjin ${ }^{\circledR}$ " locally consists of five plant materials namely: Black cutch- Bark (Acacia polyacentha), orchid bush-Bark (Bauhinia rufescens), Gum Arabic tree-Bark (Acacia Senegal), Baobab-leaves (Adensonia digitata), GarlicYellow-bulb (Allium sativum). It was claimed to have immunostimulatory activity by the local herbal medical practioners. Consequently, it is widely used by some local people in the area for boosting immunity. In our previous study on this PHF, we demonstrated its potential immunostimulatory activity on neutrophil function and humoral immune response [27]. This attract our interest to investigate its activity on cytokines as well as cell mediated immune response. To demonstrate a typical cell mediated immune response in vivo we employ Delayed type hypersensitivity (DTH) response. It involves antigen presenting cells, $\mathrm{T}$ cells and chemotactic cytokines [28]. This kind of response is important in immunomodulation, allergy and autoimmunity [29, 30]. The response is due to extravasation of $\mathrm{T}$ lymphocytes into specific sites in tissues [31].

\section{Materials ANd Methods Plant Extract}

The aqueous extract of the PHF was collected from the Department of Immunology, School of Medical Laboratory Sciences which was initially stored and preserved at $5^{\circ} \mathrm{C}$ in airtight bottles and was labelled as PHF aqueous extracts. About $0.1 \mathrm{~g}$ of the dried extract was dissolved in $1 \mathrm{ml}$ of distilled water and this served as stock. The stock was prepared in batches.

\section{Animals}

A total of 24 Wistar rats of 16-18 weeks old, weight between 126-148 $\mathrm{g}$ of either sex (11 Females; 13 Males) were used in this study. The animals were purchased from the Department of Veterinary Pharmacology, Faculty of Veterinary Medicine, Ahmadu Bello University (ABU), Zaria, Nigeria and kept in the Animal House of Faculty of Pharmaceutical sciences, Usmanu Danfodiyo University, Sokoto (UDUS), Nigeria. They were allowed to acclimatize for two weeks and fed with standard pelletized growers feed (Vital feed, Jos, Plateau) and water ad libitum. The animals were maintained under the Institutional standard laboratory conditions for experimental animal. The study was approved by Faculty of Veterinary Medicine Animal Research Ethics Committee (FAREC) with approval number as UDUS/FAREC/2019/AUPRO-3.

\section{Animal grouping and treatment}

A total of 24 Wistar rats were randomly divided into six groups and each group contains four rats. Group 1 received $10 \mathrm{ml} / \mathrm{kg}$ b.w of normal saline; Group 2 received $50 \mathrm{mg} / \mathrm{kg}$ b.w of Levamisole Hydrochloride (Guangehou Kafen Biotech Co., Ltd, China). Groups 3 received subcutaneous injection of $200 \mathrm{mg} / \mathrm{kg}$ b.w of Cyclophosphamide (Guangehou Kafen Biotech Co., Ltd, China). At day one, Group 4 6 received 250, 500 and $1000 \mathrm{mg} / \mathrm{kg}$ b.w of PHF respectively, for 14 days orally.

\section{Blood collection and processing}

On day 15, $2 \mathrm{ml}$ of blood sample was collected by cardiac puncture from each Wistar rat under Ketamine anaesthesia. The blood samples were 
Hamid KM et al., Saudi J Med Pharm Sci, Jan, 2021; 7(1): 64-70

transferred into clean plain tubes allowed to clot within 30 minutes of collection then centrifuged at $500 \mathrm{~g}$ for 5 minutes to obtain neat serum and then transferred into a labelled cryovials then immediately stored at $-20{ }^{\circ} \mathrm{C}$ until used.

\section{Measurement of Serum Cytokines Levels}

To measure the serum concentration of cytokines (i.e. IL-2, IL-4, IL-6 and IFN- $\gamma$ ), sandwichELISA technique purchased from Sunlong Biotech Co, Ltd., China was used. The procedure was carried out according to manufacturer's instructions. Assay sensitivity: IL-2 $(0.6 \mathrm{pg} / \mathrm{ml}), \mathrm{IFN}-\gamma(0.5 \mathrm{pg} / \mathrm{ml}), \mathrm{IL}-4$ $(1.2 \mathrm{pg} / \mathrm{ml})$ and IL-6 (1.5 ng/L).
Delayed Type Hypersensitivity (DTH) response

On day 7, each rat was subcutaneously injected with $0.1 \mathrm{ml}$ of normal saline containing $50 \mu \mathrm{g}$ of Keyhole Limpet Hemocyanin (KLH) (Biosearch Technologies, Inc., USA) on the right hind footpad and the left hind footpad received $0.1 \mathrm{ml}$ of normal saline only. On day 14, the right hind footpad received $0.1 \mathrm{ml}$ of normal saline only (i.e. control foot). The left hind footpad was challenged subcutaneously with $0.1 \mathrm{ml}$ of normal saline containing $50 \mu \mathrm{g}$ of KLH. The thickness of the left and right hind footpad was measured 24 hours later using RD DC 706 digital Vernier calipers (Raider Pro professional Tools Co. Ltd., China). The difference in the thickness of the right hind footpad and the left hind footpad was used as a measure of DTH reaction and was expressed as percent increment in thickness. The formula shown below was used to determine the increment [32].

\section{$\mathrm{DTH}=\quad($ Left footpad challenged with antigen - Right footpad control $) \times 100$ Left footpad challenged with antigen}

\section{Statistical Analysis}

The statistical analysis was carried out using SPSS 21 Software package (IBM, USA). Test for normality was performed to ascertain normal distribution of the variables. Data was not normally distributed based on tests of normality results: ShapiroWilk, supported by Q-Q plot. Therefore the results obtained are presented as Median. Kruskal Wallis test was carried out to explore differences on variables across the groups. Mann Whitney test was used as post hoc test to compare some groups. The $\mathrm{p}$ value $\leq 0.05$ was used to determine the level of statistical significance. However Bonferroni adjustment was used to determine the significance level of post hoc test therefore the adjusted $\mathrm{p}$-value is $\leq 0.01$.

\section{RESUlTS \\ Effect of PHF on Th1 and Th2 cytokines secretion}

The results obtained from the current study revealed there was significance difference in serum concentration of IL-2 $\left(\chi^{2}=32.97, \mathrm{p}<0.001\right)$, IFN- $\gamma\left(\chi^{2}\right.$ $=33.41, \mathrm{p}<0.001)$, IL-4 $\left(\chi^{2}=31.13, \mathrm{p}<0.001\right)$ and IL-6 $\left(\chi^{2}=32.19, \mathrm{p}<0.001\right)$ across the six groups. Among the treatment groups, group 6 (highest dose of PHF) recorded a highest median concentration score for IL-2 $(\mathrm{Md}=96.13 \mathrm{pg} / \mathrm{ml}), \mathrm{IFN}-\gamma(\mathrm{Md}=108.30 \mathrm{pg} / \mathrm{ml}), \mathrm{IL}-4$ $(\mathrm{Md}=120.39 \mathrm{pg} / \mathrm{ml})$ and IL-6 $(\mathrm{Md}=107.10 \mathrm{ng} / \mathrm{L})$ compared to the other treatment groups (Table 1). As depicted from Table 2, Post-hoc test using MannWhitney $U$ test revealed significant difference in Group 1 vs Group 6 for IL-2 and IFN- $\gamma(\mathrm{p}=0.008)$, Group 2 vs Group 6 for IL-2 (p=0.008) and Group 3 vs Group 6 $(\mathrm{p}=0.008)$ for both cytokines. The test also revealed significant difference in Group 1 vs Group 6 for IL-4 and IL-6 ( $\mathrm{p}=0.008)$, Group 2 vs Group 6 for IL-4 $(\mathrm{p}=0.008)$ and Group 3 vs Group 6 for IL-4 $(\mathrm{p}=0.002)$ and IL-6 $(\mathrm{p}=0.008)$.

Table-1: Effect of aqueous extracts of PHF on serum concentration of the Th1/Th2 cytokines

\begin{tabular}{|l|l|l|l|l|l|}
\hline \multirow{2}{*}{$\begin{array}{l}\text { Group } \\
(\mathbf{n}=\mathbf{4})\end{array}$} & \multirow{2}{*}{$\begin{array}{l}\text { Dose }(\mathbf{k g} \\
\mathbf{b . w .})\end{array}$} & $\mathbf{I L - 2}(\mathbf{p g} / \mathbf{m l})$ & IFN- $\boldsymbol{\gamma}(\mathbf{p g} / \mathbf{m l})$ & IL-4 $(\mathbf{p g} / \mathbf{m l})$ & IL-6 $(\mathbf{n g} / \mathbf{L})$ \\
\cline { 3 - 6 } & Median & Median & Median & Median \\
\hline $2(\mathrm{NS})$ & $10 \mathrm{ml}$ & 72.59 & 70.90 & 75.03 & 56.83 \\
\hline $3(\mathrm{CPV})$ & $50 \mathrm{mg}$ & 195.7 & 158.34 & 197.32 & 110.99 \\
\hline $4(\mathrm{PHF})$ & $200 \mathrm{mg}$ & 13.17 & 9.92 & 20.11 & 19.94 \\
\hline $5(\mathrm{PHF})$ & $250 \mathrm{mg}$ & 85.72 & 77.77 & 74.44 & 66.95 \\
\hline $6(\mathrm{PHF})$ & $500 \mathrm{mg}$ & 89.17 & 91.75 & 75.09 & 84.86 \\
\hline Kruskal Wallis Test & $1000 \mathrm{mg}$ & 96.13 & 108.30 & 120.39 & 107.10 \\
\hline
\end{tabular}

NS: Normal saline; CPY: Cyclophosphamide; LEV: Levamisole hydrochloride; Significant p-value is $\leq 0.05$ 
Hamid KM et al., Saudi J Med Pharm Sci, Jan, 2021; 7(1): 64-70

Table-2: Comparison between groups on the effect of aqueous extracts of PHF on the cytokines

\begin{tabular}{|l|l|l|l|l|}
\hline \multirow{2}{*}{$\begin{array}{c}\text { Group } \\
(\mathbf{n}=\mathbf{4})\end{array}$} & \multicolumn{2}{|l|}{ Th1 cytokines } & \multicolumn{2}{l|}{ Th2 cytokines } \\
\cline { 2 - 5 } & IL-2 $(\mathbf{p g} / \mathbf{m l})$ & IFN- $\boldsymbol{\gamma}(\mathbf{p g} / \mathbf{m l})$ & IL-4 $(\mathbf{p g} / \mathbf{m l})$ & IL-6 $(\mathbf{n g} / \mathbf{L})$ \\
\cline { 2 - 5 } & p-value & p-value & p-value & p-value \\
\hline 1 vs 6 & 0.008 & 0.008 & 0.008 & 0.008 \\
\hline 2 vs 6 & 0.008 & 0.751 & 0.008 & 0.597 \\
\hline 3 vs 6 & 0.008 & 0.008 & 0.002 & 0.008 \\
\hline
\end{tabular}

Post hoc test is significant at $\mathrm{p} \leq 0.01$ (with Bonferroni adjustment)

\section{Effect of PHF on Delayed Type Hypersensitivity response}

As shown in Table-3, there was significant difference in DTH response across the six groups $\left(\chi^{2}=\right.$ $32.41, \mathrm{p}<0.001)$. Among the treatment groups, Group 6 (Highest dose of PHF) recorded the highest percentage median score $(\mathrm{Md}=90.0 \%)$ compared to the other treatment groups. A post-hoc test using MannWhitney $U$ test revealed significant difference in the DTH response in Group 1 vs $6(\mathrm{p}=0.009)$ and Group 3 vs Group $6 \quad(\mathrm{p}=0.009)$. However no significant difference was observed when group 2 was compared with group $6(\mathrm{p}=0.279)$.

Table-3: Effect of aqueous extracts of PHF on DTH response

\begin{tabular}{|l|l|l|l|l|}
\hline Group (n=4) & Dose (kg b.w.) & Median (\%) & \multicolumn{2}{|l|}{ Post hoc Test } \\
\cline { 3 - 5 } & & & Comparison & p-value \\
\hline $1(\mathrm{NS})$ & $10 \mathrm{ml}$ & 65.5 & $1 \mathrm{vs} \mathrm{6}$ & 0.009 \\
\hline $2(\mathrm{LEV})$ & $50 \mathrm{mg}$ & 93.2 & $2 \mathrm{vs} 6$ & 0.279 \\
\hline $3(\mathrm{CPY})$ & $200 \mathrm{mg}$ & 35.5 & $3 \mathrm{vs} 6$ & 0.009 \\
\hline $4(\mathrm{PHF})$ & $250 \mathrm{mg}$ & 79.8 & & \\
\hline $5(\mathrm{PHF})$ & $500 \mathrm{mg}$ & 82.1 & & \\
\hline $6(\mathrm{PHF})$ & $1000 \mathrm{mg}$ & 90.0 & & \\
\hline Kruskal Wallis test: $\chi^{2}=32.41, \mathrm{p}<0.001$ & \multicolumn{3}{l}{} \\
\hline
\end{tabular}

Post hoc is significant at $\mathrm{p} \leq 0.01$ (with Bonferroni adjustment)

\section{DISCUSSION}

Scientific world recognized the impact of immunostimulatory agents in combating disease conditions but most of these immunomodulators from herbs were not scientifically evaluated [26]. Therefore it is imperative to scientifically standardize herbal formulation used for modulation of immune system as it can pave away to discover a novel drug with all the necessary requirement for treatment of disease conditions [33].

In this study we selected IFN- $\gamma$ and IL-2 to represent Th1 cytokines while IL-4 and IL-6 represent Th2 cytokines. Our finding demonstrated significant increase in the concentration of all the cytokines (IFN$\gamma$, IL-2, IL-4, IL-6) in dose dependent manner across the treatment groups. This suggest the PHF exhibit immunostimulatory effect on immune cells by inducing the secretion of Th1 and Th2 cytokines. However, not all formulation may appear to exhibit specific immunostimulatory pattern thus are difficult to define their specificity in terms of Th1/Th2 response [10, 18]. Thought some do have specific display by specifically down regulating Th1 or Th2 response but never both. Study indicates an increase in IL-2 secretion following simulative effect on Th1 subset of lymphocyte [34]. The cytokine is required for the development and maintenance of $\mathrm{T}$ regulatory (Treg) cells and for activation-induced cell death, thereby mediating tolerance and controlling unnecessary immune response that may lead to disease conditions [35]. While IL-4 is typical Th2 cytokine responsible for humoral immune response [36]. Whereas IL-6 play a vital role in the differentiation of activated $B$ cells into plasma cells which is antibody-producing cells [37]. In comparison, the competitive nature of the PHF with standard stimulatory drug is clearly shown when standard control group was compared with treatment on IFN- $\gamma$ and IL-6 level.

Herbal constituents such as tannins, alkaloids and terpenes and their secondary metabolites can serve as good source of discovering a novel drug for promoting various health conditions [3]. The qualitative phytochemical screening of the aqueous extract of the formulation shows that only Anthroquinones was absent in the constituent, however, other constituents such as Alkaloid, Terpenoids, Steroid, Cardiac Active Glycoside, Flavonoids, Saponins, Tannins, Polyphenols, Vitamins, Reducing Sugars and Photosterols were all present [38]. Flavonoid, Phenol and Glycoside enhance immunity and increase adaptive immune response [39]. In addition Polysaccharides, lectins, peptides and tannins can also modulate the immune system in various in vivo models [21]. Several phytoconstituent can increase IFN- $\gamma$ level [40]. For instance Saponins can stimulate lymphocytes and IFN- $\gamma$ [41], Polysaccharides [42], Phytophenols [43]. Similarly, Terpenoids also enhance the expression of 
IL-2 [44] and flavonoids induce expression of IL-6 [45].

In comparism, a previous study also indicated that aqueous extract of PHF can up regulate the production of IFN- $\gamma$ and IL-2 [46]. However, study of Wang and colleagues reported contrary [47]. Shin and co-workers reported upregulation of IL-4 production by PHF [48]. Similarly, Xiao and co-workers reported that a polyherbal formulation up regulate IL-6 production [49]. However studies of Kurokawa and co-workers [50] and Luo and colleagues [51] reported contrary. The disparity between this study and previous studies may be associated to differences in the PHF constituent, geographical location, soil type, variation in dose administered, antigen use in the studies to elicit immune response and probably the duration as well as mode of administration. These factors may likely dictate the result in this study.

The result on DTH response against KLH antigen reveals significant increase in paw thickness with increase in dose of the PHF across the treatment groups. This suggests that treatment with the formulation may have the ability to activate lymphocytes and other cells associated with cell mediated immune response. DTH reaction is a type IV cell-mediated immune response [52]. Differences in the paw thickness between standard drug group and highest dose treatment group was inconsiderable. This explain the competitive nature of the PHF at higher dose with Levamisole hydrochloride as standard immunostimulatory drug. Alkaloids, as phytochemical constituent of several formulations, have been reported to increase immunobioactivities which potentiated DTH reaction [53]. Another study also reported increase in DTH response after treatment with aqueous extract of PHF [54]. Similarly Bagwan and colleagues reported an increase in paw thickness after administration of PHF [55]. The paw thickness is as a result of infiltration of inflammatory cells to the site of antigen challenge in response to lymphokines secreted by sensitized $\mathrm{T}$ lymphocytes as part of cell mediated immune responses [56].

\section{Conclusion}

This study revealed that the PHF can induce the secretion of Th1/Th2 cytokines such as IL-2, IL-4, IL-6 and IFN- $\gamma$ in vivo, also increase cell mediate immune response through delayed type hypersensitivity response to KLH antigen. Immunostimulation of Th1 and $\mathrm{Th} 2$ cells by the formulation is an indication that it can be useful in managing immunosuppressed conditions due to infection, aging, malnutrition, stress etc. Therefore in-depth study on the formulation will surely yield a desired result because of its potential immunostimulatory activity on immune responses involving T lymphocytes.

\section{ACKNOWLEDGMENTS}

The authors appreciate the co-operation of $\mathrm{Mr}$. Sani Muhammad Umar (Nagge) of Al-Mustakshif Medical Health Centre, Kano, Nigeria (RC: 1393615) for the Garjin ${ }^{\circ}$ PHF. We also appreciate the effort of Mr. Abdullahi Suleiman, Mr. Abdulrasheed Ahmad and Mr. Salmanu Makama from Faculty of Pharmaceutical Science, Usmanu Danfodiyo University, Sokoto, Nigeria for the sample collection.

Conflicts of Interest: The authors declare that there is no conflict of interests.

\section{REFERENCES}

1. Gautam, R. K., Singh, D., Nainwani, R. (2013). Medicinal Plants having Anti-arthritic Potential: A Review. International Journal of Pharmaceutical Sciences Review and Research, 19(1): 96-102.

2. O'Hara, M., Kiefer, D., Farrell, K., Kemper, K. (1998). A review of 12 commonly used medicinal herbs. Archives of Family Medicine, 7(6):523-536.

3. Sulaiman, F. A., Kazeem, M. O., Ahmed, M. W., Simisade, O. T., Idris, O.A., Faridat, I. Z., Temitope, A. A., Azido, N., Oluyomi, S. A. (2014). Antimicrobial and toxic potential of aqueous extracts of Allium sativum, Hibiscus sabdariffa and Zingiber officinale in Wistar rats. Journal of Taibah University for Science, 3(8):315-322.

4. Parasuraman, S., Thing, G. S., Dhanaraj, S. A. (2014). Polyherbal formulation: concept of Ayurveda. Pharmacognosy Review, 8(16): 73-80.

5. Kevin, S., Burns, J. J., Douglas, N., Nasha, W., Steve, O., Mark, T. (2006). Modulation of Cytokine Expression by Traditional Medicines: A Review of Herbal Immunomodulators. Alternative Medicine Review, 11(2): 128-150.

6. Barik, C. S., Kanungo, S. K., Tripathy, N. K., Panda, J. R., Padhi, M. (2015). A Review on Therapeutic Potential of Polyherbal Formulations. International Journal of Current Pharmaceutical Research, 7(3): 211-228.

7. Alamgir, M., Uddin, S. J. (2010). Recent advances on the ethnomedicinal plants as immunomodulatory agents In: D. Chattopadhyay (Eds.), Ethnomedicine: a source of complementary therapeutics (pp. 227 244). Fort P.O. Kerala, India: Research Signpost.

8. Patil, U. S., Jaydeokar, A. V., Bandawane, D. D. (2012). Immunomodulators: A pharmacological review. International Journal of Pharmacy and Pharmaceutical Sciences, 4 Suppl 1: 30-36.

9. Srinivasan, S., Sundareswaran, L., Wankupar, W., Sheeladevi, R., Ravindran, R. (2016). Stress effect on humoral and cell mediated immune response: Indispensable part of corticosterone and cytokine in neutrophil function. Trials in Vaccinology, 5: 61-70.

10. Burns, J. J., Lijun, Z., Ethan, W. T., Kevin, S. (2009). The influence of traditional herbal formulas on cytokine activity. Journal of Toxicology, 23(3): 120.

11. Nage, P. N., Rajeshwari, P. (2014). An Overview on Immunomodulators. International Journal of Current 
Pharmaceutical and Clinical Research, 4(2): 108114.

12. Dhama, K., Chakraborty, S., Tiwari, R., Verma, A. K., Saminathan, M., Amarpal, Y. S. M., Nikousefat, Z., Javdani, M., Khan, R. U. (2014). A concept paper on novel technologies boosting production and safeguarding health of humans and animals. Research Opinions in Animal and Veterinary Sciences, 4(7): 353-370.

13. Spelman, K., Burns, J. J., Nichols, D., Winters, N., Ottersberg, S., Tenborg, M. (2006). Modulation of cytokine expression by traditional medicines: a review of herbal immunomodulators. Alternative Medicine Review, 11(2): 128-150.

14. Dhama, K., Saminathan, M., Siju, S. J., Mithilesh, S., Karthik, A., Ruchi, T., Lakshmi T. S., Yashpal S. M., Raj, K. S. Effect of Immunomodulation and Immunomodulatory Agents on Health with some Bioactive Principles, Modes of Action and Potent Biomedical Applications. International Journal of Pharmacology, 11(4): 253-290.

15. Kokkonen, H., Soderstrom, I., Rocklov, J., Hallmans, G., Lejon, K., Dahlqvist, S. R. (2010).UpRegulation of Cytokines and Chemokines Predates the Onset of Rheumatoid Arthritis. Arthritis Rheumatology, 62(2):383-391.

16. Bekisz, J., Sato, Y., Johnson, C., Husain, S. R., Puri, R. K., Zoon, K. C. (2013). Immunomodulatory effects of interferons in malignancies. Journal of Interferon and Cytokine Research, 33(4): 154-161.

17. Arreola, R., Quintero-Fabián, S., López-Roa, R. I., Flores-Gutiérrez, E. O., Reyes-Grajeda, J. P., CarreraQuintanar, L., Ortuño-Sahagún, D. (2015). Immunomodulation and Anti-Inflammatory Effects of Garlic Compounds. Journal of Immunology Research, 2015:401630.

18. Zuo, F., Zhou, Z. M., Zhang, Q., Mao, D., Xiong, Y. L., Wang, Y. L., Yan, M. Z., Liu, M. L. (2003). Pharmacokinetic study on the multi-constituents of Huangqin-Tang decoction in rats. Biological and Pharmaceutical Bulletin, 26(7):911-919.

19. Das, S., Bordoloi, R., Newar, N. (2014). A Review on Immune Modulatory Effect of Some Traditional Medicinal Herbs. International Journal of Pharmaceutical, Chemical and Biological Sciences, 2(1):33-42

20. Vinothapooshan, G., Sundar, K. (2011). Immunomodulatory activity of various extracts of Adhatoda vasica Linn. in experimental rats. African Journal of Pharmacy and Pharmacology, 5(3):306310.

21. Shukla, S., Mehta, A., John, J., Mehta, P., Vyas, S. P., Shukla, S. (2009). Immunomodulatory activities of the ethanolic extract of Caesalpinia bonducella seeds. Journal of Ethnopharmacology, 125(2):252256

22. Barkatullah, B. B., Ibrar, M., Niaz, A., Naveed, M., Rehmanullah. (2013). Antispasmodic potential of leaves, barks and fruits of Zanthoxylum armatum DC. African Journal of Pharmacy and Pharmacology, 7(13):685-693

23. Mukherjee, P. K., Venkatesh, P., Ponnusankar, S. (2010). Ethnopharmacology and integrative medicine
- Let the history tell the future. Journal of Ayurveda and Integrative Medicine, 1(2):100-109.

24. Zdanowicz, M. M. (2009). The pharmacology of immunosuppression. American Journal of Pharmaceutical Education, 73(8):144.

25. Sunitha, K., Krishna, M. G. (2013). Screening of Limonia acidissima fruit pulp for Immunomodulatory activity. Research Journal of Pharmaceutical, Biological and Chemical Sciences, 4 (2):439-444.

26. Lubega, A. M. B., Bbosa, G. S., Musisi, N., Erume, J., Ogwal-Okeng, J. (2013). Effect of the total crude extracts of Hibiscus sabdariffa on the immune system in the Wistar albino rats. African Journal of Pharmacy and Pharmacology, 7(26): 1942-1949.

27. Isah, S. Y., Mohammed, H. Y., Hamid, K. M., Usman, M., Mustapha, U. K. (2018). Effect of Polyherbal Formulation on Neutrophil function and TDAR in Wistar albino rat. European Journal of Pharmaceutical and Medical Research, 5(12), 563568.

28. Haque, A., Easton, A., Smith, D., O'Garra, A., Van Rooijen, N., Lertmemongkolchai, G., Titball, R. W., Bancroft, G. J. (2006). Role of T cells in innate and adaptive immunity against murine Burkholderia pseudomallei infection. Journal of Infectious Disease, 193(3):370-379.

29. Askenase, P. W., Herzog, W. R., Millet, I., Paliwal, V., Ramabhadran, R., Rochester, C., Geba, G. P., Ptak, W. (1991). Serotonin initiation of delayed-type hypersensitivity: mediation by a primitive Thy-1+ antigen-specific clone or by specific monoclonal IgE antibody. Skin Pharmacology, 4 Suppl 1, 25-42.

30. Nazimek, K., Ptak, W., Marcinkiewicz, J., Bryniarski, K. (2013). Macrophage Function in Allergic and Autoimmune Responses. Journal of Physical Therapy Health Promotion, 1(1):36-45.

31. Jacysyn, J. F., Abrahamsohn, I. A., Macedo, M. S. (2001). Modulation of delayed-type hypersensitivity during the time course of immune response to a protein antigen. Immunology, 102:373-379.

32. Smith, M. J., White, Jr. K. L. (2010). Establishment and comparison of delayed-type hypersensitivity models in the $\mathrm{B} 6 \mathrm{C} 3 \mathrm{~F} 1$ mouse. Journal of Immunotoxicology, 7(4): 308-317.

33. Majeedi, S. F., Roqaiya, M., Jahan, D., Khan, A. A. (2015). Immunomodulatory herbs of Unani medicine: A review. International Journal of herbal medicine, 3(4): 19-21.

34. Goel, A., Singh, D. K., Kumar, S. P., Bhatia, A. K. (2010). Immunomodulating property of Ocimum sanctum by regulating the IL-2 production and its mRNA Expression Using rat's splenocytes. Asian Pacific Journal of Tropical Medicine, 10: 8-12.

35. Sakaguchi, S., Yamaguchi, T., Nomura, T., Masahiro, O. (2008). Regulatory T cells and Immune Tolerance. Cell, 133(5):775-787.

36. Gharavi, M., Nobakht, M., Khademvatan, S. H., Bandani, E., Bakhshayesh, M., Roozbehani, M. (2011). The Effect of Garlic Extract on Expression of IFN- $\gamma$ and INOS Genes in Macrophages Infected with Leishmania major. Iranian Journal of Parasitology, 6(3):74-81. 
Hamid KM et al., Saudi J Med Pharm Sci, Jan, 2021; 7(1): 64-70

37. Tanaka, T., Narazaki, M., Kishimoto, T. (2014). IL-6 in inflammation, immunity, and disease. Cold Spring Harbor Perspectives in Biology, 6(10):a016295.

38. Isah, S. Y., Hamid, K. M., Muhammad, H. Y., Garba, Y. B., Yusuf, A., Abubakar, U. (2020). Phytochemical Screening, Acute Toxicity Study and Immunomodulatory activity of aqueous extract of Polyherbal Formulation in albino Wistar Rats. World Journal of Pharmaceutical Research, 9(8):165-177.

39. Chiang, L. C., Ng, L. T., Chiang, W., Chang, M. Y., Lin, C. C. (2003). Immunomodulatory activities of flavonoids, monoterpenoids, triterpenoids, iridoid glycosides and phenolic compounds of Plantago species. Planta Medica, 69(7):600-604

40. Ganju, L., Karan, D., Chanda, S., Srivastava, K. K., Sawhney, R. C., Selvamurthy, W. (2003). Immunomodulatory effects of agents of plant origin. Biomedicine and Pharmacotherapy, 57(7):296-300.

41. Cho, J. Y., Kim, A. R., Yoo, E. S., Baik, K. U., Park, M. H. (2002). Ginsenosides from Panax ginseng differentially regulate lymphocyte proliferation. Planta Medica, 68(6):497-500.

42. Li, J., Li, Q. W., Gao, D. W., Han, Z. S., Lu, W. Z. (2009). Antitumor and Immunomodulating effect of polysaccharides isolated from Solanum nigrum L. Phytotherapy Research, 23 (11): 1524-1530.

43. Murali, V. P., Kuttan, G. (2016). Curculigoside augments cell-mediated immune responses in metastatic animals. Immunopharmacology tumor-bearing Immunotoxicology, 38(4):264-269.

44. Reddy, D. B., Reddanna, P. (2009). Chebulagic acid (CA) attenuates LPS-induced inflammation by suppressing NF-kappaB and MAPK activation in RAW 264.7 macrophages. Biochemical and Biophysical Research Communications, 381(1):112117.

45. Liu, Z., Zhong, J. Y., Gao, E. N., Yang, H. (2014). Effects of glycyrrhizin acid and licorice flavonoids on LPS-induced cytokines expression in macrophage. Zhongguo Zhong Yao Za Zhi, 39(19):3841-3845.

46. Jin, R., Wan, L. L., Mitsuishi, T., Sato, S., Akuzawa, Y., Kodama, K., Kurashige, S. (1994). Effect of shika-ron and Chinese herbs on cytokine production of macrophage in immunocompromised mice. The American Journal of Chinese Medicine, 22(3-4):255266.

47. Wang, S. Y., Chen, P. F., Chang, S. T. (2005). Antifungal activities of essential oils and their constituents from indigenous cinnamon (Cinnamomum osmophloeum) leaves against wood decay fungi. Bioresource Technology, 96(7):813818.

48. Shin, S. S., Jin, M., Jung, H. J., Kim, B., Jeon, H., Choi, J. J., Kim, J. M., Cho, B. W., Chung, S. H., Lee, Y. W., Song, Y. W., Kim, S. (2003). Suppressive effects of PG201, an ethanol extract from herbs, on collagen-induced arthritis in mice. Rheumatology, 2003; 42(5):665-672.

49. Xiao, Y. H., Chen, D. P., Yan, J. H., Yokoyama, Y. (2002). Mechanism of action of Tripterygium Wilfordii polyglycoside on experimental endometriosis. European Journal of Gynaecological Oncology, 23(1):63-67.

50. Kurokawa, M., Tsurita, M., Brown, J., Fukuda, Y., Shiraki, K. (2002). Effect of interleukin-12 level augmented by Kakkon-to, a herbal medicine, on the early stage of influenza infection in mice. Antiviral Research, 56(2):183-188.

51. Luo, C. Q., Zhou, J. D., Chen, D. J. (2004). Effect of Chinese traditional medicine mixture on inflammatory response in rats with severe burn. Zhong Nan Da Xue Xue Bao Yi Xue Ban, 29(1):3234.

52. Rajan, T. V. (2003). The Gell-Coombs classification of hypersensitivity reactions: a re-interpretation. Trends in Immunology, 24(7):376-379.

53. Kannan, M., Singh, A. J. A. R., Kumar, T. T. A., Jegatheswan, P., Subburayalu, S. (2007). Studies on Immunobioactivites of Nyetanth arboriristic (oleaceae). African Journal of Microbiology Research, 1: 88-91.

54. Manjuladevi, K., Pramod, R. G., Kothai, A. R., Thenmozhi, M., Dhanalakshmi, M., Sarumathy, S. (2013). Evaluation of immunomodulatory activity of aqueous extract of a polyherbal formulation by InVivo method. Asian Journal of Pharmaceutical and Clinical Research, 6(Suppl 2):129-133.

55. Bagwan, S. A., Naikwade, N. A., Manure, J. Y. (2017). Comparative Study of Immunomodulatory Activity of Marketed Ayurvedic Formulation, Indo American Journal of Pharmaceutical Sciences, 4(12): 4776-4782.

56. Farhath, S., Vijaya, P. P., Manivannan, V. (2013). Immunomodulatory activity of geranial, geranial acetate, gingerol, and eugenol essential oils: evidence for humoral and cell-mediated responses. Avicenna Journal of Phytomedicine, 3(3): 224-230. 